\title{
LEADER AND TEAM BEHAVIOUR DURING ORGANISATIONAL CHANGE: A SYSTEMS PSYCHODYNAMIC STANCE
}

\author{
FRANS CILLIERS \\ Department of Industrial \& Organisational Psychology
}

UNISA

\begin{abstract}
The aim of this research was to explore the dynamic nature of leader and team behaviour during organisational change, using five different organisational constellations or neurotic personality styles, namely the paranoid, schizoid, depressive, compulsive and histrionic styles. Qualitative research was conducted, comprising of two focus groups with eight psychologists consulting regularly to organisational change. The data was content analysed and interpreted from the systems psychodynamic stance. Each style's leader and team behavioural manifestations are discussed. The findings and recommendations can be used by consulting psychologists towards understanding and implementing organisational change dynamics.
\end{abstract}

\section{OPSOMMING}

Die doel van hierdie navorsing was om die dinamiese aard van leier- en spangedrag tydens organisasieverandering te eksploreer, deur gebruik te maak van vyf verskillende organisasie konstelasies of neurotiese persoonlikheids style, naamlik die paranoide, skisoide, depressiewe, kompulsiewe en histrioniese style. Kwalitatiewe navorsing is uitgevoer, bestaande uit twee fokusgroepe met agt sielkundiges wat gereeld konsulteer in die veld van organisasieverandering. Die data is aan inhoudsanalise onderwerp en geinterpreteer vanuit die sisteem-psigodinamiese benadering. Elke styl se leier en span gedrag word bespreek. Die bevindinge en aanbevelings kan gebruik word deur sielkundiges in konsultasies ten einde organisasieveranderingsdinamika te verstaan en te implementeer.

It is generally accepted that all organisations are influenced by change (Campbell, 1995; Drucker, 2004; Kemp \& De Villiers, 2004; McLagan, 2002a), that change may manifest uniquely in every organisation (McLagan, 2002b; Nel, 2004), and that change management is one of the greatest challenges to the modern organisation (Haslebo \& Nielsen, 2000). Organisational change is generally defined in a reactive manner with reference to the planning and implementation of mechanistic organisational development inputs and expected outputs (McLagan, 2002c; 2003). The main focus is for example on restructuring, re-engineering and enhancing employee's coping skills in difficult times of adaptation to newness and/or difference.

For purposes of this research organisational change is defined in dynamic terms based on the belief that all organisations and its members are constantly undergoing change (Haslebo \& Nielsen, 2000). Change itself is not the problem - rather, the problem is seen as the meaning or interpretation that staff members attribute to change. For example, team members may experience management's or leadership's plans to restructure as a disparagement of their efforts and performance. The organisation is seen as a complex network of relationships between people, their ideas, mental models, values, attitudes and future dreams. Change is seen as being determined by the structure of the system and is always directed from within (far more as being controlled from the outside). Change management is not seen as linear (where one stage depends on the outcome of the previous one), but rather as a rational process that the manager or leader can think out, plan and assist staff or team members through, thus achieving the desired outcome. Change is therefore defined as any demand to operate differently in any facet of the organisation as a system (Peltier, 2001; Sperry, 2004), and which is experienced as disruptive to both the organisation and its members. A demand may originate from the macro environment, outside of the boundary of the system (such as from a turbulent economy, the professional or operational field, changes in clients and product structures) or from the micro environment inside the boundary of the system (such as from technology, structures, procedures, policies, job content, role design, culture and climate) (Gould, Stapley \& Stein, 2001). The disruptive effect on the people refers to the individual's readiness and willingness to cope with the demands of change entering his/her personal and work boundaries, versus being so filled up with anxiety that defence mechanisms are used to feel safe (Schafer, 2003). For example, Prochaska, Norcross and DiClemente (1994) identified and discussed six stages whereby the individual progresses in his/her coping with change, namely pre-contemplation, contemplation, decision, action, maintenance and recycling. This progress requires the individual's continuous awareness of the level of anxiety in the self, and how this is coped with by exploring the interaction between the self and the various objects of change (Lawrence, 1999; Miller, 1993).

Most theories and research link organisational change to leadership (see Holburn, 2003; Horth, 2003; Kotter, 2003; Nel, 2004; Nkomo, 2003), which is the organisational construct presently being referred to most in the popular as well as the academic journals (Verwey, 2003). Many grand theories and models on leadership and its roles in change management exist, and are still developing. This includes seeing leadership as a property (Kets De Vries, 2005), a skill (Ellis, 2004; Giuliani, 2004; Kotter, 2003), a task (Roodt, 2003), a belief and value system (Holburn, 2003), a competence (Horth, 2003; Steyn, 2004), a situational variable depending on the follower and a process (Robbins, Odendaal \& Roodt, 2001). There is even reference to a leadership gene determining one's effectiveness (Vermeulen, 2004). The new economy demands new leadership styles because of the ever changing intra and inter organisational relationships and the wisdom it requires to explore new ways of coping and managing. Examples are transformational (De Jager, Cilliers \& Veldsman, 2004), people (Schmikl, 2004), charismatic (Robbins et al., 2001), servant (Makwana, 2003), community (Khambula, 2003), visionary and complexity leadership (Verwey, 2003). Added to this list is containment leadership, referred to by the systems psychodynamic stance which is used in this research (Huffington, Armstrong, Halton, Hoyle \& Pooley, 2004).

For purposes of this research leadership is defined in dynamic terms as managing the boundary between what is inside versus what is outside (Miller, 1993). This implies that leadership belongs to the system that is the organisation, the individual in the designated leadership role as well as to 
followership - "the person who most clearly could discover and articulate the task in any particular situation becomes the leader" (Miller, 1993, 183).

Over the last decade many change leadership programmes have been implemented to counter-act the negative effects of change (Pretorius, 2004; Steyn, 2004). An analysis of this literature showed that most of these programmes are based upon either the functionalistic (Schmikl, 2003) or humanistic (Pretorius, 2004) views on organisational behaviour. The functionalistic view (Morgan, 1980) approaches change in a normative, concrete, tangible, regulative, ordered, structured and pragmatic manner, with the focus on policy, structure, and quickly removing the symptoms of discomfort. This view is mechanistic in its measurement of expected outcomes (Schmikl, 2003) while prescribing expected behaviours to employees. The humanistic view (Quitmann, 1985; Schneider, Bugental \& Pierson, 2001) approaches change in a sensitive manner, with the focus on the individual and the group, its humility, integrity, respect and shared values (Pretorius, 2004). This orientation is seen as positive (Snyder \& Lopez, 2002) in its focus on growth towards self-actualisation, awareness about choices and interpersonal effectiveness (Rogers, 1975; 1982) and more dynamic (than the first) in the sense that human interaction during the process of change, as well as individual coping skills, are valued (Bergh \& Theron, 1999). If organisational change is to be defined and approached as a whole system phenomenon (Sperry, 2004), it could be said that both the above views do not succeed in addressing organisational change effectively. According to Kets de Vries (1991) and Miller(1993) the functionalistic view stimulates dependence on outside authority, which is experienced as disempowering by most employees.

\section{The systems psychodynamic stance}

Argued from the assumptions of the systems psychodynamic stance, the above mentioned views on leadership during organisational change oversimplify organisational behaviour. It denies the complexity of organisational systemic functioning, its deep struggle with change and the expectancy that leadership will contain the anxiety and defensive reactions, such as resistance, denial and projection (Menzies, 1993; Miller, 1976; 1993; Neumann, Kellner \& DawsonShepherd, 1997; Obholzer \& Roberts, 1994; Huffington et al., 2004). Furthermore, it makes no provision for the complex and dynamic relationship between on the one hand strategy, structure (Miller, Kets de Vries \& Toulouse, 1982) and organisational culture (Kets de Vries, 1989, 1991; Zaleznik \& Kets de Vries, 1980) and on the other hand the personality of the top leader (Jaques, 1951, 1970; Kernberg, 1979; Kets de Vries, 1980, 1984, Zaleznik \& Kets de Vries, 1980). It is hypothesised that the traditional views towards change management defend against organisational complexity by framing leadership and its role in change in mechanistic terms, and contains the anxiety in structured inputs and recipes - as if coping with change manifests similarly in all organisational systems and personality plays no role in the behavioural process.

The systems psychodynamic stance originated at the Tavistock Institute in the UK (Miller, 1989; 1993) and incorporates Freudian system psychoanalysis, the work of Klein on child and family psychology, Ferenczi on object relations and Bertalanffy on systems thinking (Colman \& Bexton, 1975; Colman \& Geller, 1985; Czander, 1993; De Board, 1978; Gould, Stapley \& Stein, 2004; Hirshhorn, 1993; Hugg, Carson \& Lipgar, 1993; Kernberg, 1979). The stance has been used in group relations working conferences for over 50 years (Cytrynbaum \& Lee, 1993), and it developed into a organisational theory (Bion, 1961; 1970; Miller, 1976 ; 1983; 1993) as well as an organisational consultancy stance (Gabelnick \& Carr, 1989; Neumann et al., 1997).

Research on leadership during organisational change using this stance was reported by Gould, Stapley and Stein (2004),
Haslebo and Nielsen (2000), Kets de Vries (1991), Klein (2005), Lawrence (2000), Menzies (1993), Miller (1993), Obholzer and Roberts (1994). The findings indicate that employees, managers and leaders have insight into the organisation in terms of its complex inter-related systems, have understanding of its unconscious manifestations of change behaviour (eg. resistance to change because of past experiences and pain), have acquired a dynamic and proactive change coping style, and realise the role of the leader in containing anxiety and giving authorisation. The concept and role of the leader is used here to refer to any person in an appointed position of authority, such as a manager, executive or CEO (as defined by Miller, 1993). Although the literature refers to the culture and fantasies associated with organisational change, limited reference is made to the dynamic leader and team behaviour manifesting during organisational change.

\section{The systems psychodynamic leadership style typology}

The leadership typology used in this research was developed by Kets de Vries (1991), based on the work by Shapiro (1965). It was intended for use by organisational consultants to study a range of unobserved and frequently related organisational behavioural manifestations, in order to consider appropriate change interventions. This typology enjoys face validity and is highly regarded amongst the systems psychodynamic fraternity (Czander, 1993; Gould, Stapley \& Stein, 2001; Merry $\&$ Brown, 1990; Miller, 1993; Stapley, 1996). Unfortunately, the work was not explored in his further publications (eg. Kets de Vries, 2001; 2005). It is therefor not sure whether the typology applies in the post-modern, new economy world of work and the complex demands on leadership and followership to change, especially in the South African political and social change scenario. In this research the typology is extended into the domain of leadership's relatedness with team behaviour.

Shapiro (1965) argued that each individual has a specific way of thinking, perceiving and experiencing emotion. These are modes of subjective experience in general, and modes of activity that are associated with various pathologies. The individual's way of dealing with the environment and deeply embedded patterns are likely to endure. He referred to the fantasies that make up the individual's inner world, defined as the stereotyped, well rehearsed, constantly repeated ways of behaving and acting that determine the individual's particular cognitive and affective behaviour. According to Kets de Vries (1991), human functioning is generally characterized by a mixture of styles derived from these fantasies. The same individual may possess elements of many different styles, each of which is triggered by different circumstances. Among a group of individuals, however, one specific style will dominate and consistently come to the fore in situations of change. Extreme manifestations of any one style can signal significant psychopathology that seriously impairs functioning (Freedman, Kaplan \& Sadock, 1975; Nivid, Rathus $\&$ Greene, 2003).

According to Kets de Vries (1991) all organisations contain a mixture of these personality styles (where personality is seen as a large system phenomenon - see Stapley, 1996), which characterise and motivate organisational behaviour. The more centralised the organisation in terms of decision-making power being in the hands of either a top leader or a small, homogeneous, dominant coalition, the more pronounced and pure the personality type of the leader. The more power the leader has, the greater impact this personality style (in terms of fantasy and neurotic style) will have on structure, culture and strategy. Where power is broadly distributed throughout the organisation, its culture and strategies will be determined by many leaders. Also, then the relationship between style and organisational pathology becomes more complex. Although neurotic styles can have an impact at all levels of the 
organisation, it is easier to start with the understanding of leadership behaviour. Typically, top leaders show resistance to change, especially when they hold very powerful positions. Many times, adapting to change in the organisation would only occur after dramatic failure has eroded the power base of the top leader, or when he/she is replaced by another person (Merry \& Brown, 1990).

It seems that the stable and global psychological orientations of the organisation's leader(s) are major determinants of the 'neurotic styles' of the organisation (Klein, 1948; Mahler, Pine \& Bergman, 1975; Sandler \& Rosenblatt, 1962). The leader creates shared fantasies that permeate all levels, influence organisational culture, and underlie a dominant organisational adaptive style (Kernberg, 1976). This style again influences decisions about strategy and structure (Kets de Vries \& Miller, 1984a; 1984b; 1984c; 1987). Parallels can be drawn between common neurotic styles or dysfunctions of behaviour and common modes of organisational failure and pathological organisational styles. (Organisational pathology does not necessarily require the leader to exhibit these neurotic styles - some organisations might manifest such styles for completely different reasons.)

A number of common, well established organisational fantasies and neurotic styles have been identified (Merry \& Brown, 1990; Nicholi, 1988; Shapiro, 1965; Sperry, 2004), based on personality disorders as defined in the Diagnostic and Statistical Manual of Mental Disorders (DSM 1V:TR) (American Psychiatric Association, 2000). This included hypotheses about each style's predominant motivating fantasy, its emerging organisational culture, and the manifesting strategy and structure of the organisation. The study of these styles in organisational context, becomes quite complex because of its dynamic nature. Kets de Vries (1991) hypothesised that movement across organisational styles often occur depending on who is in power and the stage of the organisation's life cycle. The style of the leader may also become modified through interactions with the evolving organisation. The more extreme the style manifests in a leader and team, the more pathological the behaviour. Furthermore, a mutual causation exists - the personality of the leader can influence the organisation, and vice versa. For example, an organisation that fails in reaching its goals and feels disappointment, can cause a leader to become depressed, and competition in the system can stimulate the leader's paranoia.

The five organisational constellations/leadership styles Kets de Vries (1991) and Shapiro (1965) identified for each organisational constellation, a leadership style, culture and fantasy, namely:

1 The paranoid style and culture is suspicious and the fantasy about persecution

2 The schizoid style is detached, the culture politicised and the fantasy about detachment

3 The depressive style is dependant, the culture avoiding and the fantasy about helplessness

4 The compulsive style is rigid, the culture bureaucratic and the fantasy about control

5 The histrionic style is dramatic and narcissistic, the culture charismatic and the fantasy about grandiosity

\section{Research question and aim}

The research question was formulated as, given the five organisational constellations and leadership styles above, what are the typical system psychodynamic behaviour manifesting amongst each leadership style and team during organisational change? The aim was to explore the nature of the dynamic behaviour of each of these styles between the leader and the team during organisational change.

\section{RESEARCH DESIGN}

Research approach

The design was qualitative, explorative and descriptive in nature (Higgs \& Smith, 2003).

\section{Research methodology}

Participants

Eight psychologists were chosen who regularly consult to organisations undergoing change. They were all trained in the systems psychodynamic stance (the Tavistock group relations model).

\section{Data collection technique}

Focus groups were used, defined as a carefully planned and organised discussion designed to obtain perceptions on a defined area of interest in a permissive, non-threatening environment, by a selected group of participants sharing and responding to views, experiences, ideas, feelings and perceptions (Brewerton \& Millward, 2004; Litosseliti, 2003). Its purpose is to gain information, perspectives and empirical field texts about a specific research topic, and its rationale is to provide a sociallyoriented interaction, similar to a real life situation, where participants freely influence one another, build on oneanother's responses and thus stimulate a collective and synergistically generated thought, feeling and experience.

\section{Data collection and analysis procedure}

Two 120 minute focus groups with the researcher in the role of facilitator were conducted. Each session started with a brief overview of the organisational constellations and leadership styles. The task of the group was to generate answers to the following question: 'In your experience as a psychologist and consultant to organisations undergoing change, what specific systems psychodynamic behaviour do you see manifesting within and between each leadership style and its team'. Both sessions were tape recorded and the content transcribed. The data analysis procedure and interpretation was done according to the systems psychodynamic stance (Clarkson \& Nuttall, 2000; Czander, 1993; Hirschhorn, 1993). The procedure comprised firstly, of reading through of all responses a couple of times for familiarisation. Secondly, the responses were read through again according to Schafer's (1970) systems psychodynamic interpretive stance. Thirdly, the responses were categorised into cognitive, affective, motivational, interpersonal and leader-team behaviour. To ensure trustworthiness (as defined by Camic, Rhodes \& Yardley, 2003), the interpreted findings were discussed with half of the participants and their suggestions were incorporated into the findings.

\section{FINDINGS}

The following leader and team behaviours were identified. For each style the characteristics of the leaders are given in terms of cognitive, affective, motivational and interpersonal behaviour, followed by the nature of the leader-team relationship (which is presented in a free-flowing narrative manner). (For the sake of convenience, the leader will be referred to in the masculine singular - he/him/his, and the team in the plural.)

\section{The paranoid style}

Characteristics of the leader

1 Cognitive behaviour. He has a narrow attention span; uses facts to confirm his own worst expectations; is inclined to misread or distort facts.

2 Affective behaviour. He experiences fear (real or fantasised) and acts defensively towards his own fragility; denies the needs for change; is compulsive and rigid; has a strong need to control which may manifest in thought and action; is afraid to confront change because of the risk for exposure it holds; splits change into good and bad parts; then he becomes 
suspicious and blames something or someone (as the enemy); sometimes this enemy becomes larger in his own head; he distrusts anything new such as change initiatives; experiences anger, hostility and envy, while at the same time appearing cold and unemotional to others.

3 Motivational behaviour. He acts on his guard; protect his own boundaries; makes plans to attack the real or imagined secretive object that represent change (in order to counter any perceived threats); he has to keep the enemy at bay; is preoccupied with hidden motives and special meanings; minor issues become magnified; to have an enemy implies that everything needs to be done correctly; he does not allow himself to make mistakes.

4 Interpersonal behaviour. He acts with intensity; is hypersensitive and hyper alert; is mistrustful and envious; takes offence easily; expects deception; he may be very careful to hire, reward or promote any idea or person

\section{Leader-team relationship}

Although some suspicion in a work situation is good (for example to be aware of behavioural dynamics in the system), he brings the suspicion towards change into the team which leads to distrust; it jeopardises intra team relationships; the result is that team members feel unsafe, distrustful and un-contained; he directs his suspicion towards any object or person within or without the boundary of the team; his need is to seek for and to label an instigator of change outside of himself; he experiences change as being forced down from a powerful force outside of himself or even the team; he shows resistance towards change and what it represents; then he fights any change object and projects his fear and anxiety onto objects that represent the change for him (such as management, the union, the board, the government, the economy); he becomes the carrier of the suspicion which implies that others don't have to carry it; he acts it out on behalf of the others (such as his team); he transfers and injects his suspicion onto and into the team; which the team experiences intensely; he may then even use this team experience as evidence of paranoia in the system (as if he was not the originator and instigator); the team fears him - they feel the criticism; they feel not good-enough to live up to his requirements and expectations; sometimes he becomes depressed to the extent that the team has to take care of him emotionally; thus the team becomes the container of his anxiety; he generates competition with a strong element of fear; team members fear being 'stabbed from and in the back'; he sets himself up to continuously check out the competition; this leads to the team becoming more defensive and then they compensate by working harder to show him that he has reason to trust them; this consumes unnecessary psychological energy; he is giving the message that no one is good-enough; this view is based on his fear that someone just may be good-enough or just better than himself; his script is 'maybe you are better than me and that would be terrible'; his role becomes to ensure that no one in the team or no other team is better; often he would do an environment scan ('like a verspieder in an army') to inform the team what is going on, who the enemy is, who is worse off; he handles the politics and fighting on behalf of the team and thus becomes the container of the survival anxiety, leaving the team members to be free of that role; the team could easily fall apart under this anxiety; next the relationships across the team boundary (such as with other managers, leaders, teams) suffer; his fear is projected across the boundary onto and sometimes into other departments (projective identification).

\section{The schizoid style}

\section{Characteristics of the leader}

1 Cognitive behaviour. His cognitive deficits lead to poor performance; he is more interested in politics and social issues than work issues.

2 Affective behaviour. He is emotionally bland and schizoid; he has an inability to express enthusiasm and pleasure; his emotional deficits (such as fear) lead to a lack of concern and caring; he is cold and aloof; often bored; he defends against his hurt by isolating himself.

3 Motivational behaviour. He is unavailable; tries to avoid; does not show interest in the daily work routine.

4 Interpersonal behaviour. He fears being and feels rejected; he defends against the pain of rejection by keeping to himself; he seem to ignore the outside world, its demands and needs for change; he has little need to communicate; he avoids closeness; seems distant, hesitant, detached, withdrawn, uninvolved, unconcerned, mistrustful and unresponsive; he believes that interactions will harm him or they will fail; he acts indifferently to praise and to criticism; he seems unable to engage in reciprocal relationships.

\section{Leader-team relationship}

$\mathrm{He}$ is better at managing individuals (which he may do with some warmth) than the team; 'he is not a team player'; managing the team (or collective behaviour) is difficult for him because of its complexity; he isolates himself; he creates a sense of absence, detachment, withdrawal, avoidance and passivity; he creates an impression of incompetence in terms of not producing or having effective relationships; he does not link rationally with the team, yet he sometimes links emotionally and experientially; this means that he does not speak out or address change issues; he makes or initiates no plans for change; takes no responsibility except perhaps when he can personally gain form the venture; the result is often that the group creates fantasies about what is going on; even about their performance, future and careers; in this manner he hold some power over others (even if it is by avoidance and withholding); he fears group pressure; he mistrust the team; he alienates team members from himself and from one another; he injects fear onto and into the team; the team members realise that he is not performing well; yet they keep supporting him because of the (sometimes fantasised) emotional link; he may in a manipulative way set up a shadow leader or sub-team to manage the work as well as the relationships as in building trust, facilitating meaning and hope on his behalf; this is convenient for him as a cop-out, but the danger is that the shadow has no official authority to act on behalf of others; this could even lead to this individual or subsystem 'falling on its face' and 'burn its fingers'; this implies a (not consciously planned) set-up by the leader; leading to a split in leadership with some members experiencing being close to him while others feel excluded; this can also manifest in some people having resources (such as knowledge, power) and some not; dynamically this means that one part contains the power, knowledge and trust, while the other contains the not knowing, disempowerment and distrust; the team does not identify with the leader and what he represents; the team feels ashamed when he represents them across the team boundary; the team climate is one of limited interaction, cohesion and trust.

\section{The depressive style}

\section{Characteristics of the leader}

1 Cognitive behaviour. He shows a lack of ability and talent; he sees the organisation as a machine; he feeds the team with routine input; there is a sense of futility; he reduces his own contributions to the minimum required; he is negative and lethargic.

2 Affective behaviour. He has low self-esteem and confidence; feels worthless, insecure, inadequate, powerless, inferior, incapacitated, incompetent, helplessness, angry and guilty; doubts and downgrades himself; contains the not good enough in the system; practises a type of moral masochism (hostility turned inward); feels lonely, not loved and liked; experiences pain as a redemptive act; sees defeat as a just reward; he fears change and denies its need and reason.

3 Motivational behaviour. He is passive and acts purposeless; abdicates most of his responsibilities; comes across as helplessness and hopelessness; will combat his insecurity through external sources; submerges his own individuality; acts rigidly and makes use of routines and rituals even when 
he is in trouble; resists change in policy as well as planning; sees change efforts as hopeless, not adding value ('it has not worked in the past, why will it now?'); experiences a lack of power to change; puts structures in place to not transform because he does not have enough energy and ego strength to cope with and contain its demands; when requested to implement change he will postpone the demand; when forced to implement change he may put in place an unimaginative and mechanical plan, without believing in it, and causing its failure; he is in competition with change.

4 Interpersonal behaviour. He is very dependent on the team to assume the responsibility; experiences strong needs for affection, to being nurtured and protected; he shows a wariness towards others; can adapt his behaviour to please others; his reactions may stem from unpleasant past relationships; his subordinates may loose their sense of control, authority, self esteem, initiative and become unmotivated; he is emotionally and/or physically absent and unmotivated; he passively waits for others to change and then idealise those who do change; he can be mean to others behind their backs if they upset the status quo or work against him.

\section{Leader-team relationship}

He experiences the team members not liking him; his own anger leads to confusion in the team; he denies change ('I'm so depressed, I can not think about this now, or spend energy on this'); the denial of change in his own life, his depressed state and lack of energy to embrace change leads to him dumping (projecting the anxiety thereof) on the team; he is competitive believing that 'if I don't get ahead, nobody will get ahead'; he often refers to how unreachable change is or how unready the workforce is; this confuses the team to such an extent that they may act out his anger and guilt; because of his lack of energy and depression, the team may start looking after him, giving him support, caring and nurturing; it is as if the team is taking on his paranoid thoughts (that forms part of his depression); this leaves the team with his projected sadness, helplessness and hopelessness - a projective identification; this keeps the system stuck which could be seen as a self fulfilling prophecy of his own incompetence and negative beliefs about change; if he is clever enough to work beyond the depression and get into a caring position, the energy may be used to cope with change; normally the realisation comes to late, for example after the change should have been implemented already

\section{The compulsive style}

Characteristics of the leader

1 Cognitive behaviour. He is industrious and indecisive; rigid in thinking and problem solving

2 Affective behaviour. He is unrestful; acts out his anxiety in a compulsive and repetitive manner; fears making mistakes and being at the mercy of events outside of his control; is upset by unfamiliar situations and events; has strong needs for control, perfection, order, familiarity and efficiency; revels in this anal behaviour; experiences high levels of anxiety when he has to invent something new or deviate from the known; he denies himself pleasure; uses work as defence to feel good and in control; even more so when his stress level is high.

3 Motivational behaviour. He counteracts his fear by a preoccupation to master and control events; focuses on routine, repetition and his own set ways, detail, rules and regulations; for him form is more important than substance; he lacks spontaneity; is devoted to his work; may procrastinate outcomes; is preoccupied with success because of strong fear of failure; denies himself the pleasure of change.

4 Interpersonal behaviour. He acts deferentially to superiors, sometimes also with submission; is autocratic and dominant towards subordinates; demanding that they work according to his way.

\section{Leader-team relationship}

He regularly confronts himself in a masochistic manner, but he does not own the pain involved - he rather projects this on the team; this lack of owning means that he finds it extreme difficulty to change anything in himself, in the team or the larger organisational system; he can be sadistic in getting back at the team in case of high stress levels and if they disobey his demands and requirements; this happens because he is inclined to operate more cognitive than affective; is less open for projections from the team; when he plans for change he does so well in advance, making sure that he understands it, that it makes sense and represents good management; he finds simple tasks easy and complexity anxiety provoking; his plans for change are mechanistic, controlled, detailed, sometimes far fetched and unreal; he over-structures as a fight reaction (changing structures such as organigrams, job descriptions); blames management and other authority figures for the uncertainty; the structuring makes him feel in control; thus, he does not have to deal with difficult feelings, conflicts, complexity and chaos in his relationships; he may use change to suit himself while not having strong concerns about the team; he passively resists change, as long as he doesn't have to change any behaviour in himself; team members experience his style as enforced, controlled, bureaucratic, disempowering and frustrating; it allows them less opportunity for creativity, autonomy and ownership; if he owns the control, none is left for the team to work with; it seems as if the more he controls, the more the rebelliousness in the team will come to the fore; being so effective as a leader stimulates the "not good enough" in the team; he may be easily seduced by the team's positive feedback; then he may take responsibility for not finishing a task because of his need to always be perfect; he can be quite successful in tasks where little emotions and their containment are involved; also when he can trust the team and delegate authority clearly; his attention to detail can be very helpful in the team.

\section{The histrionic style}

\section{Characteristics of the leader}

1 Cognitive behaviour. He struggles with concentration and alternate between extremes of idealization and devaluation.

2 Affective behaviour. He experiences emotions very intensely (from excitement to anger and rage); he acts impulsively and panicky; he idolises himself.

3 Motivational behaviour. He acts out (sometimes overreact) in a narcissistic, grandiose, dramatic, immature, exhibitionistic manner with strong emotion; has a strong need for attention, to look good, to be in the limelight, to impress, be accepted; he prefers action, excitement and stimulation, often without substance or self discipline.

4 Interpersonal behaviour. He has a strong need for attention and to impress others; exaggerates especially about his talents and achievements; does not allow resistance or dissent from subordinates easily; need to impress and get attention; can be (although superficially) warm and charming; yet he comes across as insincere, inconsiderate, exploitative, lacking empathy and taking others for granted; has unstable relationships and often attracts dependent personalities; wants quick decisions, reactions and results.

\section{Leader-team relationship}

He has an idealised and unrealistic concept of change; this acts as a defence against his resistance to change because of his natural high level of anxiety and his panic reactions; when he does plan for change his efforts are grandiose and charismatic (such as 'putting the best ever programme on the table, better than any competitor and everybody must love it!'); he needs to impress authority figures; yet his efforts are superficial (not authentic) and shallow; his impulsive, panicky and exhibitionistic behaviour is accompanied by his demanding quick results from the team; this again may result in the team making mistakes; he needs to look good and to impress 
others, be in lime light; he is self-absorbed; from this narcissism and self-protection position, he demands credit for implementing change as if he is the sole actor in the change drama; he acts for the sake of acting and own survival and not for the sake of change; he is emotionally not available for the team (because of his obsession with himself); takes up most of the available energy for change; does not care about the team; does not act as a container for the team to explore options; his immaturity leads to him doing all the work himself; needs to look active and busy; often he loses energy by attending to more fluff than essence; is insincere in his motives; often introduces and enforces change with little planning; thus he politically manipulates and seduces others and off-loads his anxiety; he projects his incompetence onto the team in order for him to look good; he positions himself to be the saviour; his change initiatives have a destabilising effect; it incapacitates the team; even 'sadistically killing them off in order to be the king'; internally he has little interest in the change or empathy towards the team members; he gets frustrated and angry when team members offer first or 'better' solutions for change; his narcissism inhibits him from letting others flourish or succeed; he gets stuck in his own dependency; he knows he can't do the task alone and then manipulates others to do it (while not having enough resources); this makes his predictions true of 'I told you it was impossible to do'.

\section{DISCUSSION}

The findings showed that each organisational constellation and leadership style reacts in a distinctly different manner to organisational change:

The paranoid style approaches change with suspicion, distrust and blaming. The leader projects fear, suspicion and competition about change onto and into the team; the team experiences themselves as not being good enough to handle and implement change; in order to not fall apart, the team works harder in a pseudo competition to succeed and convince leadership that the work is successful; this dynamic can also cross the boundary into other teams or departments in the organisation.

The schizoid style approaches change with detachment, avoidance and withdrawal. The leader does not make contact with the team; he introjects fear, mistrust and isolation into the team; the team needs to make assumptions and fantasies about their roles, tasks and performance; the team is set up to do the work alone and to even support the leader in his emotional absence; the team struggles to identify with and feel proud of their leader.

The depressive style approaches change with dependence and helplessness. The leader is passive, unmotivated and feels rejected; he projects confusion onto and into the team; the team easily identifies with his projected feelings leading to anger, shame, guilt and sadness and feeling ashamed of the leader.

The compulsive style approaches change with mechanistic structure and control. The leader passively resists change initiatives by over structuring and controlling the planning and implementing of change in order to feel safe; he ensures that change is designed neatly and mechanistically according to his own ideas and needs; he avoids complexity and own involvement in change; the team experience being forced into the leader's views and actions, which is frustrating and disempowering; the team has no opportunity for autonomy or creativity.

The histrionic style approaches change with grandiosity to impress others. The leader may refer to his good efforts but it may not have substance; change efforts are idealised and unrealistic; his narcissism leads to him doing the work alone, leaving the team with little to think about or do; the team does not experience being contained by the leader; they feel seduced and manipulated into making the leader look good.

The findings supported Kets de Vries' typology in terms of the profound effect of the leader in determining the organisational culture (as the personality of the organisation - Stapley, 1996), and furthermore indicated the leader's influential role on the team's dynamic functioning relating to change. Based upon these findings, the following hypothesis about leadership dynamics during change was presented (as the concept was defined by Haslebo \& Nielsen, 2000):

The leader's construct of leadership is based upon his past experiences in general and specifically with significant authority figures as role models. These experiences were ingrained into his personality - the conscious as well as the unconscious, deeply embedded patterns, needs and fantasies - from where his cognitive, affective and motivational behaviour originate and which become visible in his stereotyped, well rehearsed, constantly repeated ways of behaving and acting.

Because of the inherent anxiety associated with change, the team is more than naturally dependent on the leader for the direction, management and containment of its primary task, including its cognitive, affective, motivational and interpersonal behaviour.

The leader crosses the interpersonal boundary (also with its inherent anxiety) into the space and realm of the team, bringing in his inner world as an individual as well as his authority and style as leader, it being paranoid, schizoid, depressive, compulsive or histrionic.

In the dynamic relationship between leader and team, the leader influences the team's relatedness with change as an object representing the unknown. The leader functioning purely and for a long time in any of the above five leadership styles, will not provide the necessary containment for the team to engage with change in a constructive and productive manner.

This scenario keeps the team at an impasse in terms of planning and implementing change, which is characterised by a phobic attitude of avoidance and incapability to break out of its catatonic paralysis into new possibilities of the fertile void (see Merry \& Brown, 1990).

Leadership style in itself and its deconstructive effect on the team becomes the defence against change and the unconscious collusion towards the implementation of change management initiatives (see De Jager, Cilliers \& Veldsman, 2004).

\section{Recommendations}

Linking the findings to the literature review, the following recommendations were formulated in order to assist the psychologist in understanding and implementing organisational change effectively.

Assuming that all organisations cope with change similarly, implementing change management from the outside by introducing a grand plan for structural changes and reengineering the business, may not lead to insight and understanding of the dynamic behaviour around change and the successful implementation of a change management programme.

Change from within, assuming that each organisation, its leadership's and team's coping with change are unique, complex and largely influenced by the personality and interactional style of the leader as conceptualised within the systems psychodynamic stance, would lead to in-depth insight into and understanding of the dynamic behaviour around change (see Obholzer \& Roberts, 1994). 
The change management consultant does not act as the change guru, helping leadership to control change and to change the team directly. Instead, the consultant would work with the processes of change. The purpose of the consultation is to find ways of creating new contexts, for people to claim ownership of new ideas and to investigate possibilities to incorporate them into existing relationships (Haslebo \& Nielsen, 2000).

These new contexts are co-created in a series of well planned and structured sessions which acts as containment for, firstly, understanding own dynamics and, secondly, leading to implementing change initiatives. Inclusiveness is practised by consulting to the whole system, for example the leader with his/her team or subsections thereof (see Wells, 1980).

During the sessions the consultant engages in an analysis of what change means for the system and what such experiences it has had in the past, and what the anticipated gains and losses are (see Campbell, 1995). On a more abstract level, the consultant engages in an analysis of the interrelationships of the primary task, boundaries, roles and role configurations, structure, organisational design, work culture and group processes (Miller, 1993; Neumann et al.,1997). Overt and covert dynamics and social anxieties (Menzies, 1993; Obholzer \& Roberts, 1994) are interpreted as it manifests between the leader and the team in the here-and-now of the consultation, for example the relatedness between objects and its boundary management (see Lawrence, 199), its representative value and how authority is psychologically distributed, exercised and enacted, in contrast to how it is formally invested. This implies the study of the emotional task of the leader and the team which is inherently filled with chaos, a lack of control and difficult experiences such as competition, rivalry, jealousy, envy, hate and aggression (Miller, 1976; 1993). As a result, leadership becomes difficult if not impossible especially if the leader gets caught up in the 'change missionary position' (French \& Vince, 1999). Hirschhorn (1997) referred to the difference between the leader as person (the need for vulnerability) and the leader as role (the need for organisational authority) which needs to be worked with and integrated.

French and Vince (1999) referred to the dynamic in change management as working from envy to desire as an integral part of the constructive and destructive processes underlying organisational life in these difficult times. If the desire to change is too strong, it becomes destructive to creativity. If desire is too weak, the system becomes stagnant. The consultant then assists the leader and team to work on balancing the desire for change. Envy on the other hand harbours destruction because it contains anger and hate. It is defined as the desire to break down something good, simply because it is good and does not belong to the self (Huffington et al., 2004). Envy has an inherent projective nature and is connected to narcissism and guilt. If the leader is overwhelmed by the envy he/she is placed in a position of omnipotence, continually imposing on others a guilt-engendering point of reference which has again has an impact on the whole team. The activity of holding, exercised through this implosion of the leader's ego ideal, impedes the working of desire within the team. Then the team lives under the illusion that it can only change through the action of the leader. Thus, the unconscious dynamics of desire and envy needs to be processed with the leader and team in order to move beyond these stumbling blocks towards change.

If the leader's behaviour and its effect on the team is not addressed during change initiatives, the system will stay in the social unconscious (Hopper, 2003). This means that it will exist as a constraint of social, cultural and communicational arrangements of which the system (the leader, the team and the organisation) is unaware - unaware in so far as these behaviours are not perceived (not known), and if perceived not acknowledged (denied), and if acknowledged, not taken as problematic (given), and if taken as problematic, not considered with an optional degree of detachment and objectivity.

Another model to be used is the CIBART (Cilliers \& Koortzen, in press) which offers a systematic and diagnostic way to work through the system's (individual, leadership and team) dynamic behaviour, namely its conflicts, identity, boundaries, authority, roles and tasks. This endeavours to help the leader to be more 'psychologically present' (Hirsschhorn, 1997) in his managing of the boundaries with his followers.

The ideal outcome would be for the system (the leader and the team) to realise the leader's significant position to serve as a role model in culture and team building. Therein, the focus is on pointing out the relevance of the team as a whole (consisting of individual members and subgroups, each with a unique contribution), to identify emergent processes as they take shape and to refer back to the team's cultural articulations in times of crises and opportunity, thereby acknowledging a shared history while fostering institutional memory and encouraging further transformations (Lipgar \& Pines, 2003).

On a meta level it is important to remember the notion of homeostasis (see Campbell, 1995) which could be seen as an indication of wellness. Therefore, the consultation endeavours to balance change and stability, care and control, conflict and collaboration, and to develop a spirit of enquiry (Cilliers, 2004; Obholzer \& Roberts, 1994).

More research is needed to determine the effect of the different leadership styles in different organisations and scenarios.

\section{REFERENCES}

American Psychiatric Association. (2000). Diagnostic and Statistical Manual of Mental Disorders (DSM 1V:TR). (4th Ed.) Text Revision. Washington: American Psychiatric Association.

Bergh, Z.C. \& Theron, A.L. (1999). Psychology in the work context. Johannesburg: International Thomspson.

Bion, W.R. (1961). Experiences in Groups. London: Tavistock Publications.

Bion, W.R. (1970). Attention and interpretation. London: Tavistock Publications.

Brewerton, P. \& Millward, L. (2004). Organisational research methods. A guide for students and researchers. London: Sage.

Camic, PM, Rhodes, JE \& Yardley, L. (2003). Qualitative research in psychology. Washington: APA.

Campbell, D. (1995). Learning consultation. A systemic framework. London: Karnac.

Cilliers, F. (2004). Organisational wellness conceptualised from the systems psychodynamic paradigm. $2^{\text {nd }}$ South African Work Wellness Conference, North-West University, Potchefstroom.

Cilliers, $\mathrm{F} \&$ Koortzen, P. (in press). The CIBART model of organisational diagnosis.

Colman, A.D. \& Bexton, W.H. (1975). Group Relations Reader 1. Jupiter: The A.K. Rice Institute.

Colman, A.D. \& Geller, M.H. (1985). Group Relations Reader 2. Jupiter: The A.K. Rice Institute.

Cytrynbaum, S. \& Lee, S.A. (1993). Transformations in global and organizational systems. Jupiter: A.K. Rice Institute.

Czander, W.M. (1993). The psychodynamics of work and organizations. New York: Guilford Press.

De Board, R. (1978). The psychoanalysis of organisations. London: Routledge.

De Jager, W., Cilliers, F. \& Veldsman, T. (2004). Leadership development from a systems psycho-dynamic consultancy stance. SA Journal of Human Resource Management, 1 (3), 85-92.

Drucker, P. (2004). Leadership. The new economy and Shakespeare. Management Today, 20 (3), 6. 
Ellis, L. (2004). Would you follow me. Developing effective leadership behaviour. Management Today, 20 (8), 32.

Freedman, A. M., Kaplan, H. J. \& Sadock, B. J. (1975). Comprehensive Textbook of Psychiatry. 1\&2. Baltimore: Williams \& Wilkins.

French, R. \& Vince, R. (1999). Group relations, management and organisation. New York: Oxford.

Gabelnick, F. \& Carr, A.W. (1989). Contributions to social and political science. Jupiter: A.K. Rice Institute.

Gould, L.J., Stapley, L.F. \& Stein, M. (2001). The systems psychodynamics of organisations. London: Karnac.

Gould, L.J., Stapley, L.F. \& Stein, M. (2004). Experiential learning in organisations. Applications of the Tavistock group relations approach. London: Karnac.

Guiliani, R. (2004). Leadership. Six skills to become a strong leader. Management Today, 20 (9), 6-7.

Haslebo, G. \& Nielsen, K.S. (2000). Systems and meaning. Consulting in organisations. London: Karnac.

Hirschhorn, L. (1993). The Workplace Within: psychodynamics of organizational life. Cambridge: MIT Press.

Hirschhorn, L. (1997). Reworking authority. Leading and following in the post-modern organisation. London: MIT Press.

Holburn, P. (2003). The work of leadership in unpredictable times. Management Today, 19 (9), 16-17.

Hopper, E. (2003). The social unconscious. Selected papers. London: Jessica Kingsley.

Horth, D.M. (2003). Leadership. Competencies for navigating complex challenges. Management Today, 19 (10), 4-6.

Huffington, C., Armstrong, A., Halton, W., Hoyle, L. \& Pooley, J. (2004). Working below the surface. The emotional life of contemporary organisations. London: Karnac.

Hugg, T.W., Carson, N.M. \& Lipgar, R.M. (1993). Changing group relations. The next twenty-five years in America. Jupiter: A K Rice Institute.

Jaques, E. (1951). The changing culture of a factory. London: Tavistock.

Jaques, E. (1970). Work, creativity and social justice. New York: International Universities Press.

Kemp, N. \& De Villiers, B. (2004). The language of transformation. Management Today, 20 (2), 34.

Kernberg, 0. (1976). Borderline conditions and pathological narcissism. New York: Aronson.

Kernberg, 0. (1979). Object relations theory and clinical psychoanalysis. New York: Aronson.

Kets de Vries, M. F. R. (1980). Organizational paradoxes: Clinical approaches to management. London: Tavistock.

Kets de Vries, M.F.R. (1984). The irrational executive: Psychoanalytic studies in management. New York: International Universities Press.

Kets de Vries, M. F. R. (1989). Prisoners of leadership. New York: Wiley.

Kets De Vries, M.F.R. (1991). Organizations on the Couch: Handbook of Psychoanalysis and Management. New York: Jossey-Bass.

Kets De Vries, M.F.R. (2001). The leadership mistique. A user's manual for the human enterprise. London: Prentice-Hall.

Kets De Vries, M.F.R. (2005). Characteristics of effective leadership. Management Today, 20 (10), 14-16.

Kets de Vries, M.F.R. \& Miller, D. (1984a). Group fantasies and organizational functioning. Human Relations, 37, 111134.

Kets de Vries, M.F.R. \& Miller, D. (1984b). The neurotic organization: Diagnosing and changing counterproductive styles of management. San Francisco: Jossey Bass.

Kets de Vries, M. F. R. \& Miller, D. (1984c). Neurotic style and organizational pathology. Strategic Management Journal, 5, 3555.

Kets de Vries, M. F. R. \& Miller, D. (1987). Unstable at the top: Inside the troubled organization. New York: New American Library.

Khambula, C. (2003). Leadership is as much a community activity as a business one. Management Today, 19 (9), 12-13.
Klein, L. (2005). Working across the gap. The practice of social science in organisations. London: Karnac.

Klein, M. (1948). Contributions to psychoanalysis, 19211945. London: Hogarth Press.

Kotter, J. (2003). Leading change. What leaders really do. Management Today, 19 (3),4-7.

Lawrence, W.G. (1999). Exploring individual and organisational boundaries. A Tavistock open systems approach. London: Karnac.

Lawrence W.G. (2000). Tongued with fire. Groups in experience. London: Karnac.

Lipgar, R.M. \& Pines, M. (2003). Building on Bion: Branches. London: Jessica Kingsley.

Litosseliti, L. (2003). Using focus groups in research. London: Continuum.

Mahler, M. S., Pine, F. \& Bergman, A. (1975). The psychological birth of the human infant. New York: Basic Books.

Makwana, M. (2003). True leadership. Leading with the heart of a servant. Management Today, 19 (9), 10.

Menzies, I.E.P. (1993). The functioning of social systems as a defence against anxiety. London: The Tavistock Institute of Human Relations.

McLagan, P. (2002a). Change leadership: Creating a change capable organisation. Management Today, 18 (9), 28-31.

McLagan, P. (2002b). Change leadership: Success with change. Management Today, 18 (8), 8-13.

McLagan, P. (2002c). Change leadership today. Why we need to rethink change. Management Today, 18 (7), 4-6.

McLagan, P. (2003). Change leadership: Making change everybody's business. Management Today, 18 (10), 18-20.

Merry, U. \& Brown, G.I. (1990). The neurotic behaviour of organisations. New York: Gardner.

Miller, E.J. (1976). Task and Organisation. New York: Wiley.

Miller, E.J. (1983). Work and Creativity. Occasional Paper No. 6. London: Tavistock Institute of Human Relations.

Miller, E.J. (1989). The "Leicester" Model: experiential study of group and organisational processes. Occasional Paper No. 10. London: Tavistock Institute of Human Relations.

Miller, E.J. (1993). From Dependency to Autonomy: Studies in Organisation and Change. London: Free Association Books.

Miller, D., Kets de Vries, M. F. R. \& Toulouse, J. M. (1982). Top executive locus of control and its relationship to strategy making, structure and environment. Academy of Management Journal, 25, 237253.

Morgan, G. (1980). Paradigms, metaphors and puzzle solving in organisational theory. Administrative Science Quarterly, 25 (4), 605-622.

Nel, C. (2004). High impact leadership and learning create sustainable change. Management Today, 20 (2), 16-17.

Neumann, J.E., Kellner, K. \& Dawson-Shepherd, A. (1997) Developing organisational consultancy. London: Routledge.

Nivid, J.S., Rathus, S.A. \& Greene. B. (2003). Abnormal psychology in a changing world. Upper Saddle River: Prentice Hall.

Nicholi, A.M. (1988). The new Harvard guide to modern psychiatry. Cambridge: Harvard University Press.

Nkomo, S. (2003). Sustainable leadershipd evelopment, Developing leadership not just leaders. Management Today, 19 (9), 8.

Obholzer, A. \& Roberts, V.Z. (1994). The unconscious at work. London: Routledge.

Peltier, B. (2001). The psychology of coaching. Theory and application. New York: Brunner-Routledge.

Pretorius, B. (2004). Effective leadership. A guide through challenging times. Management Today, 20 (4), 10-13.

Prochaska, J., Norcross, J. \& DiClemente, C. (1994). Changing for good. New York: Morrow.

Quitmann, H. (1985). Humanistische Psychologie. Göttingen: Verlag für Psychologie.

Robbins, S.P., Odendaal, A. \& Roodt, G. (2001). Organisational behaviour: Global and South African perspectives. Cape Town: Pearson Education.

Rogers, C.R. (1975). Encounter groups. London: Penguin. 
Rogers, C.R. (1982). Freedom to learn for the 80's. Columbus: Charles E. Merrill.

Roodt, A. (2003). Leadership: Lessons from termites. Management Today, 19 (5), 12-13.

Sandler, J. \& Rosenblatt, B. (1962). The concept of the representational world. Psychoanalytic Study of the Child, 17, 128145.

Schafer, R. (2003). Insight and interpretation. The essential tools of psychoanalysis. London: Karnac.

Schmikl, E. (2003). Stategy centered leadership using the leadership scorecard. Management Today, 19 (9), 27-29.

Schmikl, W. (2004). Are you a good leader-manager of people. Management Today, 19 (10),34-35

Schneider, K.J., Bugental, J.F.T. \& Pierson, J.F. (2001). The handbook of humanistic psychology. Thousand Oaks, CA: Sage.

Shapiro, D. (1965). Neurotic Styles. New York: Basic Books.

Snyder, C.R. \& Lopez, S.J. (2002). Handbook of positive psychology. Oxford, UK: Oxford University Press.
Sperry, L. (2004). Executive coaching. The essential guide for mental health professionals. New York: BrunnerRoutledge.

Stapley, L.F. (1996). The personality of the organisation. London: Free Association.

Steyn, P. (2004). Organisational strategy. Leadership excellence needed. Management Today, 19 (10), 46.

Vermeulen, J. (2004). Making sense of leadership. Management Today, 20 (9), 22-24.

Verwey, A. (2003). Why is leadership suddenly such a big issue? Management Today, 19 (8), 8-9.

Wells, L. (1980). The group-as-a-whole: A systemic socioanalytical perspective on interpersonal and group relations. In C.P. Alderfer \& C.L. Cooper (Eds). Advances in experiential social processes, 2, 165-198.

Zaleznik, A. \& Kets de Vries, M. F. R. (1980). Power and the corporate mind. Chicago: Bonus Books. 